\title{
Heliana Baia Evelin Soria e o Serviço Social no Pará
}

\section{Heliana Baia Evelin Soria and Social Work in Pará}

\section{Maria Antonia Cardoso Nascimento \\ Assistente social, professora do Curso de Graduação e \\ Pós-Graduação em Serviço Social da Universidade \\ Federal do Pará - UFPA. \\ maraiaant@ufpa.br}

\section{Vera Lúcia Batista Gomes}

Assistente social, professora do Curso de Graduação e Pós-Graduação em Serviço Social da Universidade Federal do Pará - UFPA. veragomesbelem@hotmail.com

\section{Sandra Helena Ribeiro Cruz}

Assistente social, professora do Curso de Pós-Graduação de Serviço Social da Universidade Federal do Pará e diretora dessa Faculdade. cruz.sandra761@gmail.com

É com muita honra que aceitamos o convite da Cortez Editora para elaborar este texto sobre a professora Heliana Baia Evelin Soria, como forma de homenagem e reconhecimento do seu legado para o Serviço Social no estado do Pará e, por conseguinte, para a região Norte do Brasil.

A professora Heliana Baia Evelin Soria, paraense, nascida em Belém do Pará, foi casada com o escritor argentino Antonio
Soria, com quem criou dois filhos: Alegria Baia Evelin Soria e Justo Baia Evelin Soria. Ingressou como discente do curso de Serviço Social na Universidade Federal do Pará em 1962, concluindo-o em 1968, com o trabalho intitulado "Aspectos Negativos do Assistencialismo ao Serviço Social de Grupo". Nessa universidade, em 1972, integra o corpo docente do mencionado curso. A dedicação à vida acadêmica a tornou uma das pioneiras a obter títulos de Pós-Graduação no contexto do Serviço Social local.

Mestre e doutora em Serviço Social pela Pontifícia Universidade Católica de São Paulo (PUC-SP), em 1980 defendeu a dissertação intitulada Diagnóstico individual, sob orientação da Profa. Dra. Dilséa Adeodata Bonetti, e em 1994, a tese de doutorado Serviço Social no contexto da cultura, sob orientação da Profa. Dra. Maria Lúcia Martinelli. Estes trabalhos, publicados em forma de livros (o primeiro pela Cortez Editora no mesmo ano de sua defesa, 1980, e o segundo pela Editora Appris, em 2014), não deixam dúvidas sobre a influência da Sociologia Compreensiva de Max Weber na produção intelectual de Heliana Baia, como era conhecida no âmbito do Instituto de Ciências Sociais Aplicadas (ICSA/UFPA).

A condição de única docente com o título de doutor a levou a assumir, em 1996, a coordenação do Curso de Mestrado em Serviço Social na UFPA, o primeiro da região Norte do Brasil. Nesta condição, além da atividade de ensino, orientou inúmeras dissertações de mestrado e bolsistas de ini- 
ciação científica, principalmente relativas aos temas cultura, envelhecimento humano e resiliência. A atividade de extensão também foi realizada pela professora no âmbito acadêmico. Assumiu no início dos anos 2000 a coordenação do Programa de Extensão "Universidade da Terceira Idade", implantado na UFPA em 1991, e do Programa "Luamim: peças interventivas da realidade", com foco na criança e adolescente. Essas atividades articulavam-se com os Grupos de Estudos e Pesquisas "Envelhecimento Humano na Amazônia", intitulado "SENECTUS", e "Resiliência na Amazônia", com a participação ativa de docentes e discentes do curso de Serviço Social e Psicologia da UFPA.

Como resultados das experiências em pesquisa e extensão, publicou os seguintes livros: Opúsculo de ética, (1999); Velhice cidadã: um processo em construção (2008). Em coautoria com Jorgeane Ribeiro e Leomara Rodrigues (discentes do curso de Mestrado em Serviço Social - UFPA), organizou Serviço Social e Resiliência na Ótica dos Direitos Humanos. Todos pela editora da UFPA (Edufpa).

As contribuições no âmbito da docência, pesquisa e extensão podem ainda ser ilustradas pela conquista do Prêmio Jovem Extensionista 2011 (na qualidade de orientadora), promovido pela Pró-Reitoria de Extensão (PROEX), e o Prêmio Cultura Viva $2^{\mathrm{a}}$ edição, organizado pelo Ministério da Cultura através do Centro de Pesquisa em Educação, Cultura e Ação Comunitária (CENPEC), pela classificação, entre as 120 melhores iniciativas do Brasil, ${ }^{1}$ do Programa "Luamim: peças interventivas da realidade".

Ademais, na sua trajetória profissional, registra-se na década de 1980 a presidência do Conselho Regional de Assistentes Sociais - CRAS/1 $1^{\text {a }}$ Região, hoje, Conselho Regional de Serviço Social.

Heliana Baia foi até 1992 a única docente negra do curso de Serviço Social da UFPA, reproduzindo a realidade do quadro docente das universidades brasileiras quase inteiramente branco, devido ao vigor do racismo étnico-racial presente no país. As desigualdades raciais têm sido analisadas pelos intelectuais e ativistas antirracismo como um campo de relações sociais que conformam as tensões e as contradições presentes no mercado de trabalho e, mais além, na realidade social. Nesse sentido, Heliana Baia também representa um pioneirismo para a comunidade acadêmica e profissional do Serviço Social do estado do Pará, uma exemplar história de vida profissional digna de ser publicizada.

Belém, 23 de julho de 2016.

Recebido em 23/7/2016

Aprovado em 26/7/2016

1. Foram inscritas 3.000 experiências de extensão universitária no Brasil. 